\title{
National survey of intensive care trainees' experience of and training in tracheostomy and laryngectomy management
}

\author{
L Paton $^{1 *}$, T Monro-Somerville $^{2}$, A Gibson ${ }^{2}$, L Gemmell $^{1}$ \\ From ESICM LIVES 2015 \\ Berlin, Germany. 3-7 October 2015
}

\begin{abstract}
Introduction
Recent studies in the United Kingdom [1],[2] have highlighted serious shortfalls in the care of patients with a tracheostomy or laryngectomy. Such patients potentially require time-critical, decisive airway management, likely involving resident intensive care clinicians. However, previous regional studies identified critical care trainees as inadequately trained and experienced to confidently manage airway emergencies in neck breathers [3].
\end{abstract}

\section{Objectives}

We surveyed Scottish intensive care trainees to ascertain whether such deficits are widespread and persistent.

\section{Methods}

Trainees were invited to complete a web-based questionnaire on three occasions in June 2014. Responses in the form of ticked boxes or free text were collated and analysed for trends.

\section{Results}

Ninety-nine trainees replied, of whom 96 were based in anaesthesia, one in emergency medicine and two in allied medical specialties. Alarmingly, 70 respondents (71\%) had been involved in managing an airway emergency in a patient with a tracheostomy or laryngectomy, 63 (90\%) on a critical care unit and $40(57 \%)$ on a general ward. Deficits in staff training and equipment were identified as contributory by $28(40 \%)$ and $10(14 \%)$ respondents, respectively. Most trainees (68\%) felt quite confident in caring for neck breathers, with confidence increasing as training progressed. However, the majority of trainees

${ }^{1}$ Victoria Infirmary, Glasgow, United Kingdom

Full list of author information is available at the end of the article accrued such confidence through exposure to these patients on theatre lists (80\%). Only a minority had participated in simulated emergencies (33\%) or a formal training course (14\%). Almost half (49\%) rated their training as deficient or absent and the vast majority (96\%) felt there was a place for more formal tuition in caring for patients with a tracheostomy or laryngectomy.

\section{Conclusions}

Our findings suggest that we are failing to prepare trainees for the challenges of managing airway emergencies in neck breathers. Divergence of anaesthesia and intensive care training in the UK may further compound this problem by reducing exposure to controlled subglottic airway management in theatre. The Scottish Intensive Care Society Trainee Committee has sought to address these deficits in training and reduce the burden of avoidable harm by incorporating sessions on tracheostomy management into its educational programme.

\section{Authors' details \\ 'Victoria Infirmary, Glasgow, United Kingdom. '2Royal Infirmary, Edinburgh, United Kingdom.}

Published: 1 October 2015

\section{References}

1. Cook TM, Woodall N, Harper J, et al: Major complications of airway management in the UK: results of the Fourth National Audit Project of the Royal College of Anaesthetists and the Difficult Airway Society. British Journal of Anaesthesia 2011, 106:632-42.

2. National Confidential Enquiry into Patient Outcome and Death. On the Right Trach? A review of the care received by patients who underwent a tracheostomy: NCEPOD London; 2014, http://www.ncepod.org.uk/2014tc. htm Accessed 30 August 2014.

3. Taylor C, Barrass L, Drewery H: Training for tracheostomy. British Journal of Anaesthesia 2013, 111:842-3.

\section{SpringerOpen $^{\odot}$}

( 2015 Paton et al.; This is an Open Access article distributed under the terms of the Creative Commons Attribution License (http:// creativecommons.org/licenses/by/4.0), which permits unrestricted use, distribution, and reproduction in any medium, provided the original work is properly cited. 
doi:10.1186/2197-425X-3-S1-A678

Cite this article as: Paton et al: National survey of intensive care

trainees' experience of and training in tracheostomy and laryngectomy

management. Intensive Care Medicine Experimental 2015 3(Suppl 1):A678.

\section{Submit your manuscript to a SpringerOpen ${ }^{\mathcal{D}}$ journal and benefit from:}

- Convenient online submission

- Rigorous peer review

- Immediate publication on acceptance

- Open access: articles freely available online

- High visibility within the field

- Retaining the copyright to your article

Submit your next manuscript at $\gg$ springeropen.com 